Eur. J. Clin. Chem. Clin. Biochem.

Vol. 30, 1992, pp. 217-222

(C) 1992 Walter de Gruyter \& Co. Berlin · New York

\title{
Measurement of Eleven Serum Proteins by Microparticle-Enhanced Nephelometric Immunoassay
}

\author{
By P. Montagne, P. Laroche, Thérèse Bessou, Marie Louise Cuillière, P. Varcin and J. Duheille
}

Laboratoire d'Immunologie, Faculté de Médecine, Nancy, France

(Received September 10, 1991/January 21, 1992)

Summary: Eleven proteins (immunoglobulins IgG, IgA, IgM, orosomucoid, $\alpha_{1}$-antiproteinase, haptoglobin, ceruloplasmin, C-reactive protein, transferrin, prealbumin and $\alpha_{2}$-macroglobulin) in human serum were quantitated by a new microparticle-enhanced nephelometric immunoassay. This is a one step competitive assay, based on the nephelometric measurement of light scattered by clusters of protein-coated microparticles specially synthesized for that use. Statistical evaluation (precision, recovery and method comparison) shows that the determination of serum proteins is reliable and accurate for wide ranges of concentration and that the method is quite adequate for strongly increased concentrations. This microparticle-enhanced nephelometric immunoassay appears to offer an alternative method for routine measurement of a great variety of serum proteins at high and intermediate concentrations, which are usually quantified by radial immunodiffusion or conventional immunonephelometry. On account of its sensitivity, it can also be used for the determination of relatively low concentrations of analytes.

\section{Introduction}

The synthesis of special microparticles which serve as a solid-phase for antigen-antibody reactions has been reported (1). These microparticles are monodisperse, hydrophilic and polyfunctional microspheres to which proteins can be covalently bound. The light scattered during agglutination of microparticle-protein conjugates with specific antibodies is measurable with a specially designed nephelometer. Nephelometric measurement of the light scattered during inhibition of this agglutination by free proteins (fig. 1) allows their sensitive quantitation (detection limit lower than $1 \mu \mathrm{g} / \mathrm{l})(2)$. These studies have led to the development of a new microparticle-enhanced nephelometric immunoassay (Nephelia ${ }^{\circledR}$, Diagnostics Pasteur, Marnes, France). The present report describes this competitive immunoassay and its application to the quantitation of eleven serum proteins at high and intermediate concentrations in human serum: immunoglobulins IgG, IgA, IgM, orosomucoid, $\alpha_{1}$-antiproteinase, haptoglobin, ceruloplasmin, C-reactive protein, transferrin, prealbumin, and $\alpha_{2}$-macroglobulin.

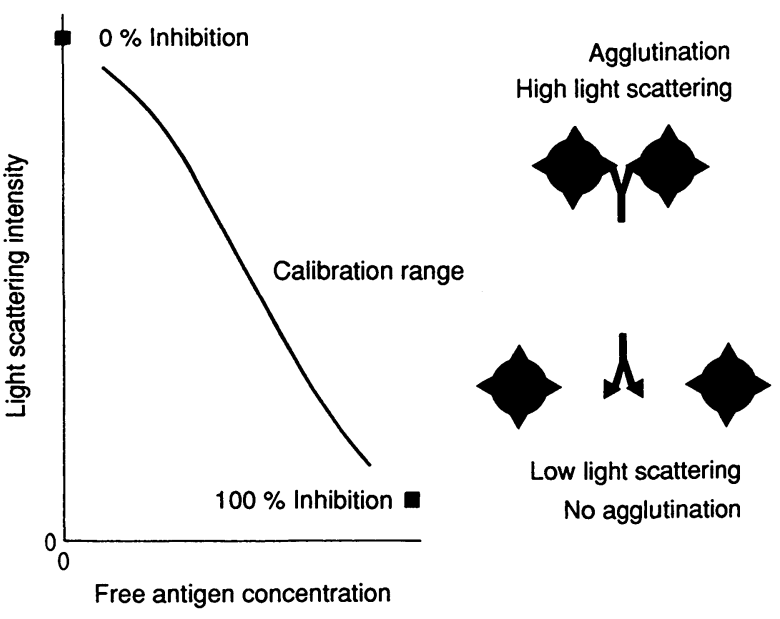

Fig. 1. Assay of free antigen by its inhibition of the agglutination of microparticle-antigen conjugate in the presence of specific antibody: change of the light scattering intensity during this inhibition as a function of the free antigen concentration.

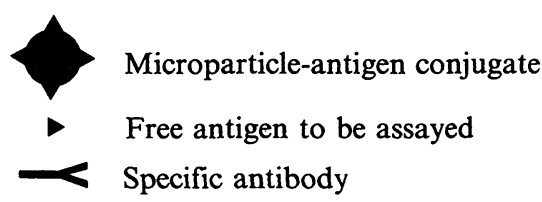




\section{Materials and Methods}

\section{Reagents}

Acrolein, 2-hydroxyethyl methacrylate, and methacrylic acid, were from Merck (Darmstadt, Germany). N, $N^{\prime}$-methylene diacrylamide was from Eastman Kodak (Rochester, NY). Sodium dodecyl sulphate, hydroquinone, boric acid, sodium chloride, 2-aminoethanol, sucrose and sodium azide were from Prolabo Rhône Poulenc (Paris, France). Protein determinations were carried out with the phosphate buffer for nephelometry, $\mathrm{pH}$ 7.2, provided by Diagnostics Pasteur.

Purified proteins (IgG, IgA, IgM, orosomucoid, C-reactive protein, and prealbumin) were kindly supplied by Diagnostics Pasteur or produced $\left(\alpha_{1}\right.$-antiproteinase, haptoglobin, ceruloplasmin, transferrin and $\alpha_{2}$-macroglobulin) by the Centre $\mathrm{Na}$ tional de Transfusion Sanguine (Paris, France). Heavy chains of $\operatorname{IgG}(\gamma)$ and IgM $(\mu)$ were prepared by reduction-alkylation of disulphide bridges and separated by gel filtration (Sephadex G-100, Pharmacia, Uppsala, Sweden) (2). The purity of all protein preparations was checked by polyacrylamide gel electrophoresis and immunoelectrophoresis.

Goat or rabbit antisera, human standard and control sera were Diagnostics Pasteur products. They were standardized according to the rules of the Sociéte Française de Biologie Clinique approved by the International Federation of Clinical Chemistry. Protein concentrations of standard and control sera were determined by radial immunodiffusion.

Human sera used for precision, recovery and correlation studies were collected from routinely tested patients of the University Hospital of Nancy (France). They were stored at $4{ }^{\circ} \mathrm{C}$ or frozen at $-20^{\circ} \mathrm{C}$.

\section{Microparticle-protein conjugates}

Microparticles were synthesized as previously reported (1): a mixture of distilled acrolein $(1.01 \mathrm{~mol} / \mathrm{l})$, 2-hydroxyethyl methacrylate $(0.46 \mathrm{~mol} / \mathrm{l})$, methacrylic acid $(0.03 \mathrm{~mol} / \mathrm{l}), \mathrm{N}, \mathrm{N}^{\prime}$-methylenediacrylamide $(0.01 \mathrm{~mol} / \mathrm{l})$ and sodium dodecyl sulphate $(0.003 \mathrm{~mol} / \mathrm{l})$ was gamma-irradiated $\left({ }^{60} \mathrm{Co}, 25 \mathrm{krad} / \mathrm{cm}^{2} \cdot \mathrm{h}, 3 \mathrm{~h}\right)$. The microparticle suspension thus obtained was stored for several years at $4{ }^{\circ} \mathrm{C}$ with hydroquinone $(0.009 \mathrm{~mol} / \mathrm{l})$.

For coating, each protein $(0.4 \mathrm{~g}$ of $\operatorname{IgG}$ heavy chain, $3.3 \mathrm{~g} \mathrm{IgA}$, $1.2 \mathrm{~g}$ of IgM heavy chain, $0.5 \mathrm{~g}$ orosomucoid, $1.1 \mathrm{~g} \alpha_{1}$-antiproteinase, $1.7 \mathrm{~g}$ haptoglobin, $2.6 \mathrm{~g}$ ceruloplasmin, $3.0 \mathrm{~g} \mathrm{C}$-reactive protein, $0.6 \mathrm{~g}$ transferrin, $1.6 \mathrm{~g}$ prealbumin, or $3.6 \mathrm{~g} \alpha_{2}$-macroglobulin) was mixed with microparticles $(10 \mathrm{~g})$ in $0.1 \mathrm{~mol} / 1$ borate buffer $\mathrm{pH} 8.2,0.3 \mathrm{~mol} / 1 \mathrm{NaCl}(1 \mathrm{l})$ and incubated for $18 \mathrm{~h}$ at $4^{\circ} \mathrm{C}$. 2-Aminoethanol was then added to the binding mixture $(0.12 \mathrm{~mol} / \mathrm{l}, 4 \mathrm{~h})$ to block unreacted groups of the microparticles. Centrifugation $\left(8000 \mathrm{~g} 1 \mathrm{~h}, 4^{\circ} \mathrm{C}\right)$ on a discontinuous sucrose gradient $(200 / 800 \mathrm{~g} / \mathrm{l})$ served to eliminate uncoupled proteins. These uncoupled proteins were measured by conventional immunonephelometry to determine the binding yields. Microparticle-protein conjugates were stored at $4{ }^{\circ} \mathrm{C}$ in $0.1 \mathrm{~mol} / 1$ borate buffer $\mathrm{pH} 8.2$ containing $0.3 \mathrm{~mol} / 1 \mathrm{NaCl}$ and $0.03 \mathrm{~mol} / 1 \mathrm{NaN}_{3}$.

\section{Procedure of protein determinations}

Microparticle-enhanced nephelometric immunoassay of serum proteins is a one step assay: $50 \mu \mathrm{l}$ of microparticle-protein conjugate $(0.5$ to $2.0 \mathrm{~g} / \mathrm{l}), 10$ to $50 \mu \mathrm{l}$ of serum standard ( 5 or 6 serial dilutions) or diluted $(1 / 100$ to $1 / 1000)$ sera (control or unknown), and $50 \mu$ l of prediluted antiserum $(1 / 100$ to $1 / 2000)$ were mixed with the buffer for nephelometry to give a final volume of $500 \mu \mathrm{l}$, in disposable microcuvettes (Nephelia cuvette Diagnostics Pasteur). All dilutions were carried out with an automated dilutor (Hamilton AG, Bonaduz, Switzerland). After $30 \mathrm{~min}$ or $1 \mathrm{~h}$ at room temperature, light scattering was measured with a specially designed nephelometer (Nephelia
N600, Diagnostics Pasteur) (2) equipped with an helium-neon laser (wavelength, $632.8 \mathrm{~nm}$ ). Spline-smoothed calibration curves (fig. 1) and unknown sample concentrations were calculated with a microcomputer (MBC 885, Sanyo Electric Co., Tokyo, Japan) fitted to the nephelometer.

\section{Evaluation study}

The precision of the assays was assessed by measuring normal and pathological concentrations of each protein in human sera, 10,20 or 30 times during the same assay (within-run precision) and on 5 to 15 different days (between-run precision). The precision was expressed as the coefficient of variation (\%).

Recovery studies were carried out by adding increasing amounts of each purified protein to several human sera with a low or normal protein content. One hundred and twenty overloadings were performed in this way, and the results subjected to linear regression analysis (recovered $=b+a$ added). For each protein, the null hypothesis $\mathrm{H}_{0}$, intercept $\mathrm{b}=0$ and slope $\mathrm{a}=1$, versus the alternative hypothesis $\mathrm{H}_{1}$, intercept $\mathrm{b} \neq 0$ and slope $a \neq 1$, were tested by $\mathrm{F}$ (Fisher) and $\mathrm{t}$ (Student), respectively.

For comparison of methods, proteins were measured in human sera (1084 sera with widely ranging concentrations for all of the eleven proteins), using radial immunodiffusion (NOR-Partigen, Behring, Marburg, Germany) for IgG, C-reactive protein, and prealbumin, and conventional immunonephelometry (Behring Laser Nephelometry) for IgG, IgA, IgM, orosomucoid, $\alpha_{1}$-antiproteinase, haptoglobin, ceruloplasmin, C-reactive protein, transferrin, prealbumin, and $\alpha_{2}$-macroglobulin. The Array System Beckman (Fullerton, CA) was used for IgG, IgA, and transferrin and the Technicon RA-1000 System (Tarrytown, $\mathrm{NY}$ ) for IgG, IgA, C-reactive protein and transferrin. In addition, C-reactive protein was assayed by fluorescence polarisation (TDx Abbott, Chicago, IL). These assays were carried out strictly following the manufacturer's recommendations. Linear regression analysis was performed for each comparison and a $95 \%$ confidence interval was calculated for each correlation coefficient which was used as a measure of the closeness of the association.

Rheumatoid factors were determined in human sera with a latex-slide agglutination test (latex-RF reagent, Behring).

\section{Results}

\section{Microparticle-protein conjugates}

Copolymerization of acrylic monomers produced microspheres of $235 \mathrm{~nm}$ (standard deviation $=3 \mathrm{~nm}$, $\mathrm{n}=36$ ) diameter with a mean yield to $63 \%$. Proteins were covalently bound to the microparticles by formation of imine bonds between aldehyde groups of the microsphere and primary amino groups of the proteins (binding yield from 23 to 100\%). Microparticle-protein conjugate suspensions remained immunoreactive for six months at least when they were stored at $4{ }^{\circ} \mathrm{C}$ with $\mathrm{NaN}_{3}(0.03 \mathrm{~mol} / \mathrm{l})$.

\section{Calibration ranges}

Decreasing sigmoidal inhibition curves (fig. 1) were observed for all serum protein determinations. Calibration ranges are given table 1 . The limits of each calibration range corresponded to protein concentrations giving light scattering intensity significantly dif- 
ferent (3 SD upper and 3 SD lower at least) from the light scattered by dispersed microparticle-antigen conjugate alone ( $0 \%$ agglutination) and by aggregated microparticle-antigen conjugate in the presence of antiserum (100\% agglutination). Calibration ranges allowed the measurement of normal as well as higher and lower pathological concentrations. Under-estimation of the highest pathological concentrations was avoided by the used inhibition mode.

Tab. 1. Calibration ranges for eleven serum proteins

\begin{tabular}{ll}
\hline Protein & Calibration range $(\mathrm{g} / \mathrm{l})$ \\
\hline IgG & $1.35-43.70$ \\
IgA & $0.25-8.00$ \\
IgM & $0.04-10.46$ \\
Orosomucoid & $0.23-3.65$ \\
$\alpha_{1}$-Antiproteinase & $0.44-7.10$ \\
Haptoglobin & $0.45-7.25$ \\
Ceruloplasmin & $0.065-2.080$ \\
C-reactive protein & $0.003-0.200$ \\
Transferrin & $0.30-9.69$ \\
Prealbumin & $0.038-1.200$ \\
$\alpha_{2}$-Macroglobulin & $0.26-8.40$ \\
\hline
\end{tabular}

Tab. 2. Within-run precision

\begin{tabular}{|c|c|c|c|c|}
\hline Protein & $\begin{array}{l}\text { Num- } \\
\text { ber of } \\
\text { data }\end{array}$ & $\begin{array}{l}\text { Mean } \\
(\mathrm{g} / \mathrm{l})\end{array}$ & $\begin{array}{l}\text { Standard } \\
\text { deviation } \\
(\mathrm{g} / \mathrm{l})\end{array}$ & $\begin{array}{l}\text { Coeffi- } \\
\text { cient of } \\
\text { variation } \\
(\%)\end{array}$ \\
\hline IgG & $\begin{array}{l}30 \\
20 \\
30\end{array}$ & $\begin{array}{r}1.58 \\
8.55 \\
18.40\end{array}$ & $\begin{array}{l}0.10 \\
0.40 \\
1.09\end{array}$ & $\begin{array}{l}6.3 \\
4.7 \\
5.9\end{array}$ \\
\hline $\operatorname{IgA}$ & $\begin{array}{l}30 \\
20 \\
20\end{array}$ & $\begin{array}{l}0.27 \\
2.78 \\
5.72\end{array}$ & $\begin{array}{l}0.03 \\
0.08 \\
0.24\end{array}$ & $\begin{array}{l}9.5 \\
2.8 \\
4.2\end{array}$ \\
\hline $\operatorname{IgM}$ & $\begin{array}{l}10 \\
10\end{array}$ & $\begin{array}{l}1.74 \\
3.58\end{array}$ & $\begin{array}{l}0.13 \\
0.31\end{array}$ & $\begin{array}{l}7.5 \\
8.7\end{array}$ \\
\hline Orosomucoid & $\begin{array}{l}10 \\
10\end{array}$ & $\begin{array}{l}0.95 \\
1.95\end{array}$ & $\begin{array}{l}0.02 \\
0.09\end{array}$ & $\begin{array}{l}2.1 \\
4.8\end{array}$ \\
\hline$\alpha_{1}$-Antiproteinase & $\begin{array}{l}10 \\
10\end{array}$ & $\begin{array}{l}2.30 \\
6.94\end{array}$ & $\begin{array}{l}0.04 \\
0.19\end{array}$ & $\begin{array}{l}1.7 \\
2.7\end{array}$ \\
\hline Haptoglobin & $\begin{array}{l}10 \\
10\end{array}$ & $\begin{array}{l}1.50 \\
4.35\end{array}$ & $\begin{array}{l}0.05 \\
0.13\end{array}$ & $\begin{array}{l}3.3 \\
3.0\end{array}$ \\
\hline Ceruloplasmin & $\begin{array}{l}10 \\
10\end{array}$ & $\begin{array}{l}0.42 \\
1.24\end{array}$ & $\begin{array}{l}0.02 \\
0.06\end{array}$ & $\begin{array}{l}5.0 \\
5.2\end{array}$ \\
\hline C-reactive protein & $\begin{array}{l}20 \\
20 \\
30 \\
10\end{array}$ & $\begin{array}{l}0.0152 \\
0.0515 \\
0.1087 \\
0.1520\end{array}$ & $\begin{array}{l}0.0014 \\
0.0012 \\
0.0032 \\
0.0103\end{array}$ & $\begin{array}{l}9.3 \\
2.4 \\
2.9 \\
6.8\end{array}$ \\
\hline Transferrin & $\begin{array}{l}30 \\
20 \\
20\end{array}$ & $\begin{array}{l}0.66 \\
4.19 \\
7.79\end{array}$ & $\begin{array}{l}0.04 \\
0.12 \\
0.20\end{array}$ & $\begin{array}{l}5.6 \\
2.8 \\
2.6\end{array}$ \\
\hline Prealbumin & $\begin{array}{l}20 \\
20 \\
20\end{array}$ & $\begin{array}{l}0.0553 \\
0.1137 \\
0.2231\end{array}$ & $\begin{array}{l}0.0037 \\
0.0050 \\
0.0157\end{array}$ & $\begin{array}{l}6.6 \\
4.4 \\
7.0\end{array}$ \\
\hline$\alpha_{2}$-Macroglobulin & $\begin{array}{l}10 \\
10\end{array}$ & $\begin{array}{l}2.69 \\
8.39\end{array}$ & $\begin{array}{l}0.05 \\
0.06\end{array}$ & $\begin{array}{l}1.9 \\
0.7\end{array}$ \\
\hline
\end{tabular}

\section{Evaluation study}

Tables 2 and 3 present the within-run and betweenrun precision results, respectively. The coefficients of variation calculated for large distributions of analyte concentration ranged between $0.7 \%$ and $9.5 \%$ for the within-run and between $0.7 \%$ and $9.6 \%$ for the between-run study.

All the analytical recovery results are reported in table 4. Percentage recovery was very close to $100 \%$ for all eleven proteins. Statistical studies of the parameters of the linear regression (recovered $=b+a$ added) performed for each protein over a large concentration range showed that the intercepts (b) were never significantly different from 0 ( $\mathrm{P}<0.05)$, and the slopes (a) were not significantly different from $1(\mathrm{P}<0.05)$, except for IgG (1.03) and C-reactive protein (1.05).

Linear regression parameters computed for each of the 22 comparisons between methods are given in table 5. Correlation coefficients ranged from 0.92 to 0.99 , except for 2 comparisons (IgG and transferrin)

Tab. 3. Between-run precision

\begin{tabular}{|c|c|c|c|c|}
\hline Protein & $\begin{array}{l}\text { Num- } \\
\text { ber of } \\
\text { data }\end{array}$ & $\begin{array}{l}\text { Mean } \\
(\mathrm{g} / \mathrm{l})\end{array}$ & 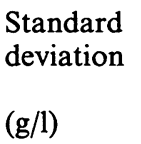 & $\begin{array}{l}\text { Coeffi- } \\
\text { cient of } \\
\text { variation } \\
(\%)\end{array}$ \\
\hline IgG & $\begin{array}{l}10 \\
10 \\
10\end{array}$ & $\begin{array}{r}4.41 \\
9.08 \\
17.34\end{array}$ & $\begin{array}{l}0.23 \\
0.45 \\
1.13\end{array}$ & $\begin{array}{l}5.1 \\
4.9 \\
6.5\end{array}$ \\
\hline $\operatorname{IgA}$ & $\begin{array}{l}10 \\
12 \\
10\end{array}$ & $\begin{array}{r}0.65 \\
5.34 \\
10.99\end{array}$ & $\begin{array}{l}0.05 \\
0.16 \\
0.84\end{array}$ & $\begin{array}{l}7.2 \\
3.0 \\
7.6\end{array}$ \\
\hline IgM & $\begin{array}{l}5 \\
5\end{array}$ & $\begin{array}{l}1.65 \\
3.43\end{array}$ & $\begin{array}{l}0.14 \\
0.33\end{array}$ & $\begin{array}{l}8.5 \\
9.6\end{array}$ \\
\hline Orosomucoid & $\begin{array}{l}5 \\
5\end{array}$ & $\begin{array}{l}0.95 \\
1.85\end{array}$ & $\begin{array}{l}0.02 \\
0.11\end{array}$ & $\begin{array}{l}2.3 \\
5.9\end{array}$ \\
\hline$\alpha_{1}$-Antiproteinase & $\begin{array}{l}5 \\
5\end{array}$ & $\begin{array}{l}2.27 \\
6.81\end{array}$ & $\begin{array}{l}0.11 \\
0.29\end{array}$ & $\begin{array}{l}4.8 \\
4.3\end{array}$ \\
\hline Haptoglobin & $\begin{array}{l}5 \\
5\end{array}$ & $\begin{array}{l}1.55 \\
4.47\end{array}$ & $\begin{array}{l}0.12 \\
0.20\end{array}$ & $\begin{array}{l}7.5 \\
4.5\end{array}$ \\
\hline Ceruloplasmin & $\begin{array}{l}5 \\
5\end{array}$ & $\begin{array}{l}0.42 \\
1.24\end{array}$ & $\begin{array}{l}0.02 \\
0.07\end{array}$ & $\begin{array}{l}5.3 \\
5.3\end{array}$ \\
\hline C-reactive protein & $\begin{array}{l}10 \\
10 \\
10 \\
10\end{array}$ & $\begin{array}{l}0.0123 \\
0.0541 \\
0.1095 \\
0.1400\end{array}$ & $\begin{array}{l}0.0009 \\
0.0017 \\
0.0037 \\
0.0130\end{array}$ & $\begin{array}{l}7.6 \\
3.1 \\
3.4 \\
9.3\end{array}$ \\
\hline Transferrin & $\begin{array}{l}10 \\
10 \\
15\end{array}$ & $\begin{array}{l}2.21 \\
4.51 \\
8.62\end{array}$ & $\begin{array}{l}0.13 \\
0.16 \\
0.45\end{array}$ & $\begin{array}{l}6.0 \\
3.5 \\
5.3\end{array}$ \\
\hline Prealbumin & $\begin{array}{l}10 \\
10 \\
10\end{array}$ & $\begin{array}{l}0.0596 \\
0.1163 \\
0.4754\end{array}$ & $\begin{array}{l}0.0045 \\
0.0042 \\
0.0219\end{array}$ & $\begin{array}{l}7.5 \\
3.6 \\
4.6\end{array}$ \\
\hline$\alpha_{2}$-Macroglobulin & $\begin{array}{l}5 \\
5\end{array}$ & $\begin{array}{l}2.66 \\
8.42\end{array}$ & $\begin{array}{l}0.04 \\
0.06\end{array}$ & $\begin{array}{l}1.5 \\
0.7\end{array}$ \\
\hline
\end{tabular}


Tab. 4. Analytical recovery

\begin{tabular}{|c|c|c|c|c|c|c|c|c|c|}
\hline \multirow[t]{2}{*}{ Protein } & \multirow{2}{*}{$\begin{array}{l}\text { Range } \\
\text { investigated } \\
(\mathrm{g} / \mathrm{l})\end{array}$} & \multirow{2}{*}{$\begin{array}{l}\text { Num- } \\
\text { ber of } \\
\text { data }\end{array}$} & \multicolumn{2}{|c|}{$\begin{array}{l}\text { Recovery } \\
(\%)\end{array}$} & \multicolumn{3}{|c|}{$\begin{array}{l}\text { Linear regression } \\
\text { (recovered }=\mathrm{b}+\mathrm{a} \text { added })\end{array}$} & \multirow{2}{*}{$\begin{array}{l}\text { Significance } \\
\mathrm{F} \text { test for } \\
\mathrm{b}=0 \text { vs } \mathrm{b} \neq 0\end{array}$} & \multirow{2}{*}{$\begin{array}{l}\text { Significance } \\
\mathrm{t} \text { test for } \\
\mathrm{a}=1 \text { vs } \mathrm{a} \neq 1\end{array}$} \\
\hline & & & Mean & $\mathrm{SD}$ & $\mathrm{b}(\mathrm{g} / \mathrm{l})$ & a & $\mathbf{r}$ & & \\
\hline IgG & $4.9-41.0$ & 18 & 100.6 & 4.9 & -0.29 & 1.03 & 0.998 & $0.75 \mathrm{NS}$ & 1.83 \\
\hline IgA & $0.93-5.80$ & 8 & 101.2 & 4.5 & 0.09 & 1.02 & 0.972 & $0.32 \mathrm{NS}$ & $0.38 \mathrm{NS}$ \\
\hline IgM & $1.12-3.60$ & 8 & 95.4 & 5.0 & -0.10 & 0.98 & 0.968 & $0.38 \mathrm{NS}$ & $0.26 \mathrm{NS}$ \\
\hline Orosomucoid & $0.87-2.48$ & 6 & 101.8 & 3.6 & 0.06 & 0.99 & 0.983 & $0.88 \mathrm{NS}$ & $0.34 \mathrm{NS}$ \\
\hline$\alpha_{1}$-Antiproteinase & $2.55-5.22$ & 10 & 101.4 & 2.2 & 0.11 & 0.93 & 0.981 & $0.66 \mathrm{NS}$ & $1.23 \mathrm{NS}$ \\
\hline Haptoglobin & $1.65-6.60$ & 8 & 101.9 & 5.3 & 0.02 & 1.02 & 0.993 & $0.07 \mathrm{NS}$ & $0.40 \mathrm{NS}$ \\
\hline Ceruloplasmin & $0.95-1.90$ & 10 & 95.4 & 4.7 & 0.08 & 0.97 & 0.983 & $0.92 \mathrm{NS}$ & $0.54 \mathrm{NS}$ \\
\hline C-reactive protein & $0.025-0.125$ & 23 & 104.1 & 7.5 & -0.001 & 1.05 & 0.997 & $0.71 \mathrm{NS}$ & 2.73 \\
\hline Transferrin & $1.28-7.34$ & 20 & 99.2 & 3.4 & -0.14 & 1.05 & 0.992 & $1.01 \mathrm{NS}$ & $1.57 \mathrm{NS}$ \\
\hline$\alpha_{2}$-Macroglobulin & $2.12-4.80$ & 9 & 102.0 & 2.4 & -0.12 & 1.04 & 0.992 & $0.81 \mathrm{NS}$ & $0.71 \mathrm{NS}$ \\
\hline
\end{tabular}

NS: not significant at $\mathrm{P}<0.05$

Tab. 5. Comparison with other methods

\begin{tabular}{|c|c|c|c|c|c|c|c|}
\hline \multirow[t]{2}{*}{$\begin{array}{l}\text { Compared } \\
\text { method }\end{array}$} & \multirow[t]{2}{*}{ Protein } & \multirow{2}{*}{$\begin{array}{l}\text { Range investigated } \\
\text { (compared method) } \\
\text { (g/l) }\end{array}$} & \multirow{2}{*}{$\begin{array}{l}\text { Number } \\
\text { of } \\
\text { samples }\end{array}$} & \multicolumn{3}{|c|}{$\begin{array}{l}\text { Linear regression } \\
(Y=b+a \text { compared method })\end{array}$} & \multirow[t]{2}{*}{$\begin{array}{l}95 \% \text { confidence } \\
\text { interval for } r\end{array}$} \\
\hline & & & & $\mathrm{b}(\mathrm{g} / \mathrm{l})$ & $\mathrm{a}$ & $r$ & \\
\hline $\begin{array}{l}\text { Radial immuno- } \\
\text { diffusion }\end{array}$ & $\begin{array}{l}\text { IgG } \\
\text { C-reactive protein } \\
\text { Prealbumin }\end{array}$ & $\begin{array}{l}3.6-37.0 \\
0.010-0.121 \\
0.10-0.44\end{array}$ & $\begin{array}{l}53 \\
18 \\
60\end{array}$ & $\begin{array}{c}0.89 \\
-0.003 \\
0.01\end{array}$ & $\begin{array}{l}1.04 \\
1.176 \\
0.87\end{array}$ & $\begin{array}{l}0.96 \\
0.99 \\
0.98\end{array}$ & $\begin{array}{l}0.93-0.97 \\
0.97-0.99 \\
0.96-0.99\end{array}$ \\
\hline $\begin{array}{l}\text { Behring } \\
\text { laser } \\
\text { nephelometry }\end{array}$ & $\begin{array}{l}\text { IgG } \\
\text { IgA } \\
\text { IgM } \\
\text { Orosomucoid } \\
\alpha_{1} \text {-Antiproteinase } \\
\text { Haptoglobin } \\
\text { Ceruloplasmin } \\
\text { C-reactive protein } \\
\text { Transferrin } \\
\text { Prealbumin } \\
\alpha_{2} \text {-Macroglobulin }\end{array}$ & $\begin{array}{l}3.3-38.2 \\
1.16-10.20 \\
0.65-9.94 \\
0.66-2.90 \\
1.76-4.98 \\
0.23-7.50 \\
0.24-1.69 \\
0.010-0.133 \\
1.77-9.82 \\
0.08-0.40 \\
1.28-9.50\end{array}$ & $\begin{array}{l}81 \\
45 \\
40 \\
45 \\
44 \\
45 \\
70 \\
45 \\
44 \\
60 \\
37\end{array}$ & $\begin{array}{l}-0.68 \\
0.02 \\
-0.34 \\
0.28 \\
0.50 \\
0.002 \\
0.21 \\
0.006 \\
0.04 \\
0.03 \\
0.14\end{array}$ & $\begin{array}{l}0.98 \\
1.03 \\
0.80 \\
0.84 \\
0.84 \\
0.964 \\
1.16 \\
0.964 \\
0.91 \\
0.95 \\
0.86\end{array}$ & $\begin{array}{l}0.96 \\
0.95 \\
0.94 \\
0.97 \\
0.97 \\
0.99 \\
0.93 \\
0.98 \\
0.97 \\
0.98 \\
0.98\end{array}$ & $\begin{array}{l}0.94-0.98 \\
0.91-0.97 \\
0.89-0.96 \\
0.95-0.98 \\
0.94-0.98 \\
0.98-0.99 \\
0.89-0.96 \\
0.96-0.99 \\
0.94-0.98 \\
0.96-0.99 \\
0.96-0.99\end{array}$ \\
\hline $\begin{array}{l}\text { Beckman } \\
\text { Array System }\end{array}$ & $\begin{array}{l}\text { IgG } \\
\text { IgA } \\
\text { Transferrin }\end{array}$ & $\begin{array}{l}4.3-32.1 \\
1.09-9.16 \\
1.43-5.12\end{array}$ & $\begin{array}{l}52 \\
56 \\
60\end{array}$ & $\begin{array}{l}0.20 \\
0.34 \\
0.59\end{array}$ & $\begin{array}{l}1.00 \\
0.80 \\
1.18\end{array}$ & $\begin{array}{l}0.86 \\
0.98 \\
0.86\end{array}$ & $\begin{array}{l}0.77-0.92 \\
0.96-0.99 \\
0.77-0.91\end{array}$ \\
\hline $\begin{array}{l}\text { Technicon } \\
\text { RA } 1000\end{array}$ & $\begin{array}{l}\text { IgG } \\
\text { IgA } \\
\text { C-reactive protein } \\
\text { Transferrin }\end{array}$ & $\begin{array}{l}3.9-32.8 \\
0.92-9.50 \\
0.010-0.188 \\
1.10-4.74\end{array}$ & $\begin{array}{l}70 \\
74 \\
28 \\
34\end{array}$ & $\begin{array}{c}-0.66 \\
-0.05 \\
0.013 \\
0.21\end{array}$ & $\begin{array}{l}0.95 \\
0.96 \\
0.802 \\
1.03\end{array}$ & $\begin{array}{l}0.92 \\
0.97 \\
0.97 \\
0.94\end{array}$ & $\begin{array}{l}0.87-0.95 \\
0.95-0.98 \\
0.93-0.99 \\
0.88-0.96\end{array}$ \\
\hline Abbott TDx & $\mathrm{C}$-reactive protein & $0.003-0.090$ & 23 & 0.003 & 1.108 & 0.97 & $0.93-0.99$ \\
\hline
\end{tabular}

with the Array System Beckman (0.86). For some sera, ceruloplasmin, prealbumin and particularly Creactive protein concentrations were below the limit of detection of the reference methods. These were rejected from our study, although they were measurable by microparticle-enhanced nephelometric immunoassay. No effect (such as a under- or overevaluation of results) of rheumatoid factors, which were found in some sera, was detected in microparticle-enhanced nephelometric immunoassay or in the comparison methods.

\section{Discussion}

Radial immunodiffusion (3) and conventional immunonephelometry (4) are commonly used to measure high and intermediate concentrations of serum proteins, but these methods have certain drawbacks. A prolonged diffusion time (from 24 to $48 \mathrm{~h}$ ) is necessary to obtain reliable results by radial immunodiffusion, and it is ill-adapted for large numbers of samples. Although it is an easy-to-perform method, conventional immunonephelometry has poor sensitiv- 
ity $(1 \mathrm{mg} / \mathrm{l})$, requiring a blank measurement of diluted samples and clarification of turbid samples by pretreatment (5). Furthermore, in conventional immunonephelometry, as in all immunoassays based on an uncompetitive reaction, there is a risk of error when the antigen is in excess.

The microparticle-enhanced nephelometric immunoassay described in this work and used to measure eleven serum proteins, preserves the advantages of conventional immunonephelometry and avoids some of its drawbacks.

It is a highly sensitive assay (detection limit lower than $1 \mu \mathrm{g} / \mathrm{l}$ ) allowing a great dilution of samples $(1 / 1000$ to $1 / 50000$ in the reaction mixture) even for proteins that are present in very low concentrations. Such dilutions removed any interference due to turbidity, sample blank measurement, or sample pretreatment. Although this high sensitivity was not required for the determination of the most serum proteins tested in this work, it permitted the assay of proteins such as ceruloplasmin, prealbumin, and particularly C-reactive protein, whose concentration in some sera used in the comparison study was below the limit of detection of radial immunodiffusion and conventional immunonephelometry.

Microparticle-enhanced nephelometric immunoassay is a rapid ( $30 \mathrm{~min}$ to $1 \mathrm{~h}$ ), fully automatable one step assay, which is suitable for the measurement of a great number of samples ( 360 per hour), but also easy to use and therefore suitable for emergencies.

The inhibition mode, chosen for the determination of serum proteins, enables analyte underevaluation in antigen excess conditions to be eliminated and provides the possibility of assaying haptens $(6,7)$.

Precision studies showed that adequate assay ranges for the quantitation of the eleven tested proteins were easily covered with an accuracy that was comparable to and sometimes better than that of conventional immunonephelometry and radial immunodiffusion $(8-11)$, in spite of a larger dilution of samples. Recovery studies showed a close agreement between the theoretical and measured concentrations except for IgG and C-reactive protein (slight over-recovery). Method comparison indicated a generally strong correlation between the concentrations measured by microparticle-enhanced nephelometric immunoassay and by the reference methods.

Microparticle-enhanced nephelometric immunoassay using microparticles and a nephelometer specifically conceived for that use, thus appears to offer an alternative method for routine determination of a great variety of serum proteins at high and intermediate concentrations. It has been also used to quantify proteins in other biological fluids such as cerebrospinal fluid (2) and milk (12-15) and other biological molecules with lower concentration $(1,6,7)$. In addition to these above-mentioned reports, this work shows the general applicability of the method.

\section{Acknowledgements}

This study was supported in part by grants 81 MO835 and 84 M1121 from the Ministère Français de la Recherche et de la Technologie. P. Montagne is a research engineer, Institut National de la Santé et de la Recherche médicale. M. L. Cuillière is a study engineer, Centre National de la Recherche Scientifique.

\section{References}

1. Duheille, J., Pau, B. \& Gros, P. (1982) Réactif permettant un dosage de trés haute sensibilité de l'antigène caractéristique du virus de l'hépatite $\mathrm{B}$ dans les liquides biologiques humains, European Patent EPO 0104101B1, Sanofi (France).

2. Cuillière, M. L., Montagne, P., Bessou, Th., El Omari, R., Riochet, D., Varcin, P., Laroche, P., Prud'homme, Ph., Marchand, J., Flecheux, O., Pau, B. \& Duheille, J. (1991) Microparticle-Enhanced Nephelometric Immunoassay (Nephelia $\left.{ }^{\circledR}\right)$ for Immunoglobulins G, A, and M. Clin. Chem. $37,20-25$.

3. Mancini, G., Carbonara, A. C. \& Heremans, J. F. (1965) Immunochemical quantitation of antigens by single radial immunodiffusion. Immunochemistry 2, 235-254.

4. Sieber, A. \& Gross, J. (1976) Determination of proteins by laser nephelometry. Laboratoriumsblätter 26, 117-123.

5. Voigt, H. W. (1977) Klärung lipämischer Seren durch neues Verfahren. Laboratoriumsblätter 27, 168-172.
6. Duheille, J., Montagne, P., Riochet, D., Bessou, Th., Varcin, P., Cuillière, M. L., Marchand, J. \& Pau, B. (1984) Immunonephelometric assay of serum thyroxine and triiodothyronine, in Abstracts from the Twelfth International Congress of Clinical Chemistry, Rio de Janeiro, p. 1410.

7. Gartner, A., Carles, C., Montagne, P., Cuillière, M. L. \& Duheille, J. (1991) A Microparticle Enhanced Nephelometric Immunoassay (Nephelia ${ }^{\circledR}$ ) Applied to Thymulin Measurement. J. Immunoassay 12, 521 - 542 .

8. Virella, G. \& Funderberg, H. (1977) Comparison of immunoglobulin determination in pathological sera by radial immunodiffusion and laser nephelometry. Clin. Chem. 23, 1925-1928.

9. Guiguet, M., Padieu, P. \& Mack, G. (1983) Laser nephelometric measurement of seven serum proteins compared with radial immunodiffusion. J. Clin. Chem. Clin. Biochem. $21,217-221$. 
10. Schmitz-Huebner, U., Nachbar, J. \& Asbeck, F. (1980) The determination of antithrombin III, alpha 2-macroglobulin and alpha 2-antiplasmin in plasma by laser nephelometry. J. Clin. Chem. Clin. Biochem. 18, 221-225.

11. Daigneault, R. \& Lemieux, D. (1978) Evaluation of Behring laser-nephelometer prototype in the measurement of $\mathrm{IgG}$, IgA and IgM. Clin. Biochem. 11, 28-31.

12. Montagne, P., Gavriloff, C., Humbert, G., Cuillière, M. L., Duheille, J. \& Linden, G. (1991) Microparticle-Enhanced Nephelometric Immunoassay for Immunoglobulins $G$ in Cow Milk. Lait 71, 493-499.

13. Collard-Bovy, C., Marchal, E., Humbert, G., Linden, G., Montagne, P., El Bari, N., Duheille, J. \& Varcin, P. (1991) Microparticle-Enhanced Nephelometric Immunoassay: 1Measurement of Alpha- and Kappa-Caseins. J. Dairy Sci. $74,3695-3701$.
14. Marchal, E., Collard-Bovy, C., Humbert, G., Linden, G., Montagne, P., Duheille, J. \& Varcin, P. (1991) Microparticle-Enhanced Nephelometric Immunoassay: 2-Measurement of Alpha-Lactalbumin and Beta-Lactoglobulin. J. Dairy Sci. 74, 3702-3708.

15. Humbert, G., Collard-Bovy, C., Marchal, E., Linden, G., Montagne, P., Duheille, J. \& Varcin, P. (1991) Microparticle-Enhanced Nephelometric Immunoassay: 3-Application to Milk and Dairy Products. J. Dairy Sci. 74, 3709-3715.

Paul Montagne

Laboratoire d'Immunologie

Faculté de Médecine

BP 184

F-54505 Vandœuvre les Nancy Cedex 